\title{
Escape the Lion Cage: social networks by catch zones of small-scale fisheries in the oil settlement of Lobitos (Peru)
}

\author{
Isidro Maya Jariego \\ Universidad de Sevilla, Spain \\ José F. Querevalú Miñán \\ Lourdes G. Varela \\ Javier Ávila \\ Universidad Nacional Federico Villarreal, Perú
}

\begin{abstract}
Artisanal fishing communities are often in conflict with the interests of the oil extraction industry, industrial fishing fleets and tourism. This paper considers Lobitos, a fishing enclave in northern Peru, where the oldest oil settlement in Latin America was established. The primary focus is community organization and development of the fisheries. Using a mixed methods approach, intensive ethnographic observation and analysis of the social networks of the skippers of small-scale fishing vessels was conducted by in-depth interviews with 30 artisanal fishermen, together with a social network survey involving 43 boat captains in Lobitos. The results showed the mistrust and negative attitudes of fishermen towards oil companies and the industrial fishing fleet. However, they expressed positive expectations regarding tourism development, as well as favorable attitudes towards the diversification of fishing activity through tourist services. The networks of acquaintances, social support and exchange of ecological information allowed us to identify three different groups of fishermen according to preferential fishing zones. The skippers of vessels that prefer to fish in intermediate zones have a prominent role, both in terms of local leadership and through the connection with boats belonging to other bays near Lobitos. This subgroup acts as an intermediary in the networks a whole and has an integrated vision of the coastal ecosystem. Network measures and preferential fishing zones can be used as indicators to assess the degree of availability and preparation for the implementation of new uses in the fisheries sector associated with tourism and heritage.
\end{abstract}

Key words: artisanal fisheries, social support networks, local ecological knowledge, oil industry, tourism, Peru.

\section{Introduction}

This case study considers a community of artisanal fishermen receptive to new touristrelated activities in the fisheries, despite having a negative experience in relation to the oil industry and industrial fishing respectively. The research focuses on the factors that lead to the same group to respond differently to influential, stronger economic actors with which it interacts. Lobitos, in the north of Peru, provides a convenient context to assess this evolution, since it is a traditional oil settlement that has recently begun to 
receive tourists attracted by opportunities for surfing. It is a small coastal community that depends on local resources, and is located in a poorly developed area.

The discussion first examines the interaction of the small-scale fishing community with other economic actors. Secondly, the internal structure of the community as a way to understand the readiness of artisanal fishermen groups to interact with industrial players is considered, using qualitative in-depth observation and network analysis respectively.

\subsection{The oil industry, intensive fishing and tourism and artisanal fishing communities}

Coastal areas are characterized by dense populations and a diversity of social and economic actors competing for existing resources (Allison \& Ellis, 2001; Jentoff, 2000; Salas, Chuenpagdee, Seijo \& Charles, 2007). In Latin America and the Caribbean, the interests of small-scale fisheries often conflict with industrial and recreational fishing fleets, oil exploration and tourism development (Hall, 2001; Salas et al., 2007; Voyer, Barclay, Mcllgorm \& Mazur, 2017). In this section the interaction of the artisanal communities with the oil industry, industrial fishing and tourism, is briefly reviewed.

The coexistence of fishing communities with the oil industry is complex and potentially conflicting. Offshore oil extraction increases maritime traffic, causes pollution, can damage fishing gear, and sometimes prevents access to traditional fishing grounds (Cormick \& Knaster, 1986; Stepanova, 2015). However, the coexistence of both sectors has not always resulted in a conflict between the productive exploitation of resources and the conservation of the environment. For example, the Norwegian regime has reduced conflict by establishing controls over the oil industry so as to provide sufficient guarantees for fishing, with initiatives to also prevent damage to ecosystems through ongoing consultation with the fisheries sector and provision of compensation rights for fishermen incurring financial loss (Uhre \& Leknes, 2017). Such a regulatory framework can reduce the negative impact of the oil industry on fisheries.

More direct competition is experienced with industrial fishing fleets, both because both artisanal and industrial fisheries may exploit the same species; and because of the greater technological sophistication of the latter. Artisanal fishermen in Latin America and the Caribbean frequently complain that industrial fishing invades the areas closest to the coast, degrades the seabed, and negatively affects the biological productivity of marine ecosystem (Begossi, 2006; Castilla \& Fernández, 1998). On the Peruvian coast, artisanal communities coexist with an industrial fishery that in the $1960 \mathrm{~s}$ became the largest in the world (Roemer 1970; Thorpe, Aguilar-lbarra \& Reid, 2000). Artisanal fishermen catch barely four percent of the total fish landed in Peru, despite being the main suppliers for domestic consumption (Estrella, Guevara-Carrasco, Palacios, Avila \& Medina, 2000). With high levels of debt and low bargaining power on price, small-scale fisheries are ineffective (Estrella \& Swartzman, 2010). In recent years the fishing effort of the small-scale fleet has continued to grow, while overall catch volume and volume of catches per vessel have declined (Alfaro-Shigueto et.al 2010; 
Estrella \& Swartzman, 2010). In this context, intensive fishing is usually perceived as being a major threat to the continuity of artisanal fisheries.

Relations with the tourism sector have generally been more ambivalent. On the one hand, it is considered a complementary activity, which contributes to an increase the demand for and consumption of fish, and is compatible with the seasonal activities of the fisheries (Estrella \& Swartzman, 2010). On the other hand, the economic advantages of tourism have often relegated fishing activities to a secondary place in local communities (Oracion, Miller \& Christie, 2005). In addition, tourism pressure may adversely affect the sustainability of fisheries (Fabinyi, 2008, 2010). Catches from smallscale fisheries are traditionally geared to the local tourism market; and more recently, have provide opportunities to develop alternative "fishing-tourism" activities, which coincide with an increase in recreational fishing overall (Lloret et.al. 2016). Thus tourism provides a combination of risks and opportunities for the artisanal fishing sector.

The northern coast of Peru is characterized by having both the oldest petroleum industry (Miller, 1982) and the most productive industrial fishery (Salas et al., 2007) Chile and Peru are associated with the most productive industrial fisheries in South America, accounting for almost 90 percent of catches in the region (FAO, 2000). In the case of Peru, this is predominantly an industrial fleet, whose main catch is anchovy ${ }^{1}$ (Engraulis ringens), despite the near collapse of the stock in 1972 (Agüero, 1992, Boerema \& Gulland, 1973; Csirke, 1980; Salas, Chuenpagdee, et.al., 2007). Recently, the tourism sector has begun to develop, forming an important alternative means for local development. Although conflict between the economic actors mentioned above is usually presumed, this is an area where comparatively little empirical research has been undertaken (Uhre \& Leknes, 2017). This case study thus examines the interaction of the artisanal fishing community with the oil industry, the industrial fleet and tourism development respectively, located in the same coastal area. The relationships between the internal structure of the community of artisanal fishers on the one hand and the external economic environment is considered.

\subsection{Artisanal fishing, social patterns and new economic activities in the fishing sector}

In many parts of Latin America, small-scale fisheries have a precarious existence, based on subsistence. According to Salas et al. (2007), small-scale fisheries: (a) catch a high diversity of species using different fishing gears, (b) are labor-intensive, (c) use multiple landing sites along the coast, (d) are a seasonal activity, (e) have a significant impact in terms of both employment and protein for human consumption in coastal areas, ( $f$ ) attract migrant workers, (g) rely on intermediaries for selling fish, and consequently have a poor bargaining power; and (h) barely have social protection mechanisms or unemployment coverage (p.6).

Local communities of artisanal fishermen are organized into highly cohesive, densely connected groups with high levels of social control. Fishermen spend a great

\footnotetext{
${ }^{1}$ In recent years, giant squid (Dosidicus gigas) fishing has increased, precisely as an alternative to anchovy (Estrella et al, 2000; Estrella \& Wartzman, 2010).
} 
deal of time socializing with each other at the harbor, during communal celebrations and activities, on boats and at the usual meeting places, talking about the state of the sea and fishing activity. However, they are careful to share as little information as possible about the key factors that increase catches (Acheson, 1988; Palmer, 1990). Strong relational integration coexists with secrets in fishing.

One of the elements of differentiation among fishermen is the area in which each vessel makes the catches, in relation to the distance from the port (Acheson, 1988; Maya-Jariego, Florido \& Sáez, 2016). Skippers of boats with a larger capacity engine can explore alternative fishing grounds, generate a space of differentiated sociability, are more socially prominent and develop a more integrated vision of the ecosystem (MayaJariego, Florido \& Sáez, 2017). Very cohesive groups are expected to be more reluctant to change (Flache \& Macy, 1996), while differentiation by fishing zones can lead to different ways of reacting to new tourism and commercial opportunities. That is, internal differentiation in coastal communities may assist adaptation when faced with new economic opportunities.

Diversification of fishing activity in response to tourism is a major factor transforming communities of artisanal fishermen. Tourism may have harmful effects on the marine environment (Fabinyi, 2008, Hall, 2001, Solstrand, 2013, Young, 1999); in particular, recreational fishing increases fishing pressure (Borch, 2004; Vølstad, Korsbrekke, Nedreaas, Nilsen, Nilsson, Pennington, Subbey \& Wienerroither, 2011). Nevertheless, marine tourism has also emerged as an economic alternative in areas where the fleet is oversized in relation to the catch potential (Chen, 2010), and there is a gradual transfer of families leaving the fishing sector to engage in tourism (Oracion et al., 2005). In parallel, under certain circumstances, professional fishing may develop interdependent and mutually beneficial relationships with the tourism sector (Voyer et al., 2017). Similarly, there are cases where both the cultural heritage of fishing ports and the diversification of tourism in the sector can contribute to reduction in the size of the fleet, encourage small-scale fishing and facilitate the conservation of stocks (MayaJariego, Holgado \& Florido, 2016).

\section{Study area}

Lobitos is one of six districts that make up the Talara Province in the Piura region of northern Peru (Figure 1). The first significant settlement dates back to the 1920s, coinciding with the installation of the British oil company Lobitos Oilfields Limited. Throughout this decade, the oil industry influenced community characteristics in the neighborhood of Lobitos. Immediately after the coup d'état of 1968, the Peruvian government expropriated and nationalized the oil company, as well as establishing a military base which until 1992 was the headquarters of the Eighth Division of the Peruvian Army.

The nature of the fishing community has always been determined by the decisions of the oil companies and the military base. The first fishermen came from Sechura and settled in the area known as "La Punta", near the beach. The British 
company that established the first oil installations ordered the fishermen to relocate to the Plebiscito neighborhood. Later they were moved to the Panama neighborhood. The military administration finally located them in the Primavera neighborhood, where they have remained.

The most recent economic development is tourism, attracted by the beaches and strong winds for surfing and kitesurfing. Lobitos currently has a population of around 1,600 , consisting of a community of fishermen composed of 133 families, some soldiers, and a floating population of mostly foreign tourists.

\section{FIGURE 1}

\section{Methods}

The methodology combined intensive ethnography with the analysis of the social networks of artisanal boat skippers in Lobitos. Participant observation was carried out during a continuous month of field work in May 2012, during which one of the researchers participated in the daily activities of the fishing community. During that period 30 in-depth interviews were conducted. Two fishing trips were made to observe a typical fishing day, and a photographic record of all stages of fish production was carried out (Querevalú Miñán, 2016). Subsequently periodic visits were made to corroborate the information and conduct complementary interviews.

The analysis of the skipper networks was carried out in May 2016. Quantitative data served as a contrast to previous ethnographic work. For the network analysis, a questionnaire was circulated with questions concerning fishing activity, together with a name generator of acquaintances' relationships, information exchange and social support among artisanal boat skippers. UCINET 6 (Borgatti, Everett \& Freeman, 2002), and Visone 2.9 (Brandes \& Wagner, 2004) was used for network analysis and visualization. The participants and instruments used in this second stage of the study are detailed below.

Using this combination of methods the structure of external and internal relationships of the small-scale fishing community was examined. The distribution of groups within the community provides an understanding of readiness to interact openly with the several local economic actors. The centrality indicators, the fishing zones and the connection with other coves are used to differentiate groups among Lobitos fishermen. The research follows an inductive approach to describe the relationships of a small group of fishermen with their socio-economic environment.

\subsection{Participants}

Interviewees were 43 skippers from the bay of Lobitos. The group consisted of men between 24 and 75 years old (mean age is 49.51), which on average have been engaged in fishing for 33 years $(M=33.04, S D=13.41)$. The participants have lived and fished most of their lives in Lobitos $(M=28.76, S D=13.06)$, a place with which they feel strongly identified $(M=9.60, S D=1.02)$. They also declared themselves generally committed to the protection of the marine environment $(M=9.32, S D=2.54)$. The 
identification with the world of surfing obtains lower scores, although also positive (M $=6.16, \mathrm{SD}=3.3$ ).

\subsection{Instruments}

The respondents answered a questionnaire with questions about (a) the relationships they maintain with other fishermen, whose vessels are anchored in Lobitos; (b) the relationships they maintain with skippers of other fishing enclaves; (c) data on fishing activity; and (d) attitudes towards new tourism and heritage uses in the fishing sector.

Network of skippers of boats in Lobitos. A list of 43 active boats (confirmed in the previous ethnographic fieldwork) was presented to the respondents, in which they were asked successively with whom they "have had personal contact" (personal relationships), with whom they "have shared Information on fishing or on the sea" (ecological information), and with whom they "have dealt with personal issues "(social support) in the last year (Maya-Jariego, Florido \& Sáez, 2017).

Intergroup relations. The skippers of Lobitos also provided information on their relationships with vessels of other fishing enclaves in nearby coves. In this case, they mentioned boats spontaneously, without providing them with a previous listing, thus generating a bi-modal network of Lobito boats in relation to vessels from other fishing enclaves.

Fishing activity data. In each case information was obtained on fishing gear, species caught, fishing areas frequented, as well as the years that each respondent has dedicated to fishing. They also indicated on a scale from 1 to 10 the degree of identification with Lobitos. In addition, boat owners rated a list of institutions in the area ( including municipality, non-governmental organizations, and oil companies) with a scale ranging from -4 "I have a very negative opinion" to +4 "I have a very positive opinion".

Attitudes. Respondents completed a list of 15 items to assess their attitudes towards incorporating new tourism and heritage uses in the fisheries sector, the implementation of participatory instruments and participatory governance, and the application of environmental protection measures (Maya-Jariego, Holgado \& Florido, 2016). The complete list of items can be found in Table 4, along with the four thematic factors that make up the instrument. The scale ranged from 1 "strongly disagree" to 5 "strongly agreed". The reliability obtained for the 15 items was alpha 0.6 .

\section{Results}

Lobitos owes its name to the high presence of Peruvian sea lions (arctophoca australis) on its coast ${ }^{2}$. Artisanal fishermen have traditionally lived with this species of otarids, which they consider the factor with the most impact on the productivity of the fisheries. Sea lions lurk both individually or in groups to snatch the catch and

\footnotetext{
${ }^{2}$ In Spanish, sea lions are called sea wolves ("lobos marinos"), from where derives the name of Lobitos.
} 
occasionally break fishing gear, be it nets or hooks. Accordingly, Lobitos has always been considered a difficult area for fishing.

The sea lion scares the fish... or depredates the fish that is already caught in the net or with hook. You arrive, you throw the buoy, the lead and you lay the net, and suddenly it appears. When the sea lion shows the fish no longer come afloat. It does not come, it gets scared. But it also comes out when you've finished casting the net and the fish is nearing. You feel the fish in the net, you say "let's pull the net", and then the sea lion appears... I'm not talking about one... The sea lions come from the platforms, which have now become their home. If there were no platforms they would not be there. They come down from the platforms and as the fishing is now near the platforms, they arrive fast. They have a good sense of smell, because when the fish is in the net, the fat appears. The smell is felt when you are catching bonito, you smell it. And the smell of fish reaches the sea lion. I do not speak of one when they hurt us, but two, three arrive... even a colony of sea lions we have seen. Not to exaggerate, last time we saw twenty to fifty lions per boat. When they come in a group they eat everything. [E19, crewmember, male, 35 years old]

Lobitos is in the area of influence of the Humboldt Current, one of the world's most productive marine ecosystems, but which periodically hinders fishing activity, due to its strong winds and currents.

\subsection{Coexistence with the oil industry and industrial fishing}

Artisanal fishers coexist with the oil and industrial fisheries industries. There are 35 oil platforms offshore belonging to two companies with foreign capital. There are also large vessels that direct their catch to fish processors, for the production of flour, oil and preserves. Conflicts with both groups are widely shared in the fishing community.

The oil platforms were established from the 1960s onwards. According to the artisanal fishermen, some of these are located at a distance of 2 to 10 miles from the coast, in former fishing grounds, usually on rocky sea beds with a high concentration of fish. Fishing is restricted in the vicinity of the platforms. Occasional gas or oil leaks together with waste and plastics produced by platform operations, also contaminate these locations. Some fishermen also complain that the oil companies' boats navigate through these area without noticing the location of floating gillnets, occasionally accidentally breaking these.

Oil rigs are installed in old fishing grounds. Here you were fishing and now they put this well. You come and you tie your boat to the platform to fish because that was your fishing zone and... What do they do? Their boat comes and they say: "it is forbidden to be here because of stealing." They get on your boat, they loosen your mooring. But here in Lobitos we do not steal, they steal in other ports. They are old fishing grounds of the old fishermen. Yes, because below the platform there are rocks. The platforms are mostly where there is rock, and that is where the fish is. The sea is deep because sometimes when we fish we use a line of 200 meters and in some places we even bypass the 200 meters. [E24, skipper, male, age 70]

In those wells that are at $\mathbf{3 0}$ meters... There we have fished with the line, and now when we get there they say that we will steal. They are old fishing zones, they were ours. We go there because there is fish, seriously, there is plenty. But the company does not look at that, it says that you are there to steal, and they give you a fine of 200 or 300 soles [E12, skipper, male, 82 years] 
Artisanal fishermen also indicate that their fishing grounds are invaded by industrial fishing vessels. According to our informants, both boats carrying anchovies used for flour manufacture ("bolicheras") and the trawler fleet operate very close to the beach. When this occurs, fish shoals move to other areas, reducing the availability of fish for artisanal fishermen. Trawling in particular is non-selective, degrades the seabed, negatively affects biomass, and captures smaller species that providing food for the fish mainly caught by the artisanal fleet (e.g. bonito, grouper and rock sea bass, among others). In the opinion of the interviewees, these fisheries reduce the productivity of the marine ecosystem.

The artisanal fisheries are also affected to a lesser extent by underwater fishing, carried out by foreigners visiting the locality. In strong current conditions, the artisanal fishermen move close to the rocks off the coast to fish for Peruvian rock seabass, also frequented by divers who compete for these fish stocks, due to good underwater visibility. However the interviewees who have a more open and positive attitude toward the tourism industry were clearly less critical in this case than they were of the oil industry.

\subsection{The artisanal fishing of Lobitos}

The artisanal fishermen surveyed fished on average 221 days in the previous year $(M=221.39, S D=59.66)$. This is a form of inshore fishing, less than 10 miles offshore. Among the fishing gear used, respondents indicated pinta ${ }^{3}(43,100 \%)$, floating gillnets $(27,62.8 \%)$, muestra $(19,44.2 \%)$, and espinel ${ }^{5}(4,9.3 \%)$. The most frequent species caught are Peruvian rock seabass (Paralabrax humeralis), bighead tilefish (Caulolatilus affinis), striped bonito (Sarda orientalis), graery threadfin seabass (Cratinus agassizii), and broomtail grouper (Mycteroperca xenarcha). The tonnage of the boats varies between 1 and 5.5, with an average of 2.30 (SD = 1.05). All are wooden boats, with a sail and a diesel engine of low power, operating normally within a range not exceeding five nautical miles, that is, the area reserved by the Peruvian state for artisanal fishing.

Lobitos has a fleet of 49 artisanal vessels, of which only 45 are active and 30 go fishing the whole year. The usual fishing schedule is from 3:00 a.m. to 12:00 noon, or from 5:00 a.m. to 2:00 p.m.; although in summer they make two short trips. The catch of the day is divided into three parts: most is sold, a small part goes to family consumption and a very small part is dedicated to "cataneros", who help at the pier to unload the fish. The fishermen sell their products to a group of six merchants, five of them retailers. Selling is done on the dock, when the merchandise is unloaded. Given the lack of fish conservation systems, fishermen usually work with a pre-sale system (before going fishing), which lessens negotiation capacity in the sale price.

The crew is based on kinship relationships. There are 49 ship owners and 135 crew members in Lobitos. The boats are organized in domestic units, in which the most

\footnotetext{
${ }^{3}$ It is a nylon hand line, with hook and lead.

${ }^{4}$ Fishing with lure.

${ }^{5} \mathrm{~A}$ type of longline.
} 
common crew combinations are groups of brothers (30.6\%) and parents and children (26.5\%). Fishing tasks are sustained through family and community relations, whereby minors are involved early in family tasks.

The fishermen of the locality began fishing when they were children, learning the job during the school holidays. The interviewees estimate that currently there are about 8 minors working in the artisanal fishing sector of Lobitos ( $M=7.8, S D=4.6)$, who started when they were on average around 11 years old $(M=11.2, S D=2.13)$. As far as the respondents themselves were concerned, almost half of them $(F=21,48.8 \%)$ started working when they were under 14 , the minimum working age in Peru. Almost two-thirds of the respondents claim that children start working to learn the job $(F=28,65.1 \%)$, and more than half say that they work to pay for their studies ( $F=24,55.8 \%$ ). The most common way of compensation to minors is crew shares (according to $58.8 \%$ of respondents), although in some cases only a tip or a small part of the profit is provided (29.4\%).

\subsection{Three fishing zones}

The fishing community traditionally distinguishes three fishing zones depending on the distance to the coast, which they call "shore", "center" and "outside". Each area corresponds, respectively, to a distance of less than three nautical miles (shore), between three and six miles (center) and more than six miles (outside). They are represented in Figure 2. This is a map that represents the perception of the fishermen, who indicated the habitual fishing grounds, with the colloquial term that they give each one of these. Artisanal boats do not have geo-location systems, so these are guided through observation, with visual reference points in the geography of the coast.

The map also indicates the location of the oil platforms, so that it is possible to observe how the zones vary in the concentration of fishing grounds and oil platforms. The shore is the area with the most fishing grounds, while the center has a greater relative presence of oil platforms. In the intermediate zone there are approximately one fishing ground per oil platform (1.08); in the area of the shore there are 2 fishing grounds per platform (2.08); and in the more distant area there are almost 3 fishing grounds per platform (2.75).

\section{FIGURE 2}

Fishing is distributed more or less proportionally between the three zones (Table $1)$, varying according to the season. The center is the most frequented area for fishing. The vessels use $41.23 \%$ of their fishing time in the intermediate zone, between 3 and 6 miles away. Specifically, 93 percent of the vessels fish in this area. However, despite the fact that less time is devoted to the shore area on average, most vessels (90.7\%) secure at least part of the catch in the areas closest to the shore, less than three miles away. On the other hand, the furthest area is transited by only two thirds of the vessels (67.4\%), concentrating a smaller fishing time on average.

\section{TABLE 1}


Each boat varies in the way it manages its fishing time. In order to differentiate the patterns of distribution of fishing time, a k-means clustering analysis was performed, with the Quick Cluster procedure in 10 iterations, a convergence criterion of 0.02 and the use of updated means. As classification variables, the time distribution between "shore", "center" and "outside" was used. The results with 3 categories are summarized in Table 2, which distinguishes three subgroups according to the preferred fishing location.

\section{TABLE 2}

Fishermen in more distant areas are more likely to use bottom-set gillnets, compared to those who fish near the shore $(U=75, p<.049)$, who resort more to fishing with a hook.

\subsection{Communal life versus secrecy in fishing}

In daily life, the small fishing community is exposed to opposing forces of cooperation and competition. On the one hand, fishing and communal activities offer many opportunities for interaction and socialising. On the other hand, the fishing activity is in itself a competition for resources, resulting in information control and secrecy over the most effective fishing practices.

Both fishing operations and vessel maintenance require cooperative behaviors that result in the formation of a group of highly connected and highly cohesive fishers (Figure 3). For example, hauling boats and lifting these out of the water require a large group of participants. Generally, such help is reciprocal. Fishermen show gratitude for the help provided by inviting their peers for breakfast or a lunch, reinforcing the patterns of sociability. Moreover, collaboration in the repair of fishing gear and damage of vessels is expected and help is immediate in case of breakdown or when it becomes necessary to tow a boat. In fact, the demands of the marine environment itself - with strong winds, intense currents and sea lions lurking in the area - require collaboration between peers as a strategy of adaptation.

\section{FIGURE 3}

Nevertheless, vessels compete with each other for fishery resources. Expertise, experience, local ecological knowledge and information on the marine environment are key factors for effective fishing. Through secrecy, fishermen protect those factors that can lead to a competitive advantage ${ }^{6}$.

This distinction of fellowship and informational relationships is confirmed by the comparison of the three matrices of relationships evaluated (Table 3). The data show a consistent pattern: the friendship relationship is more selective than the exchange of

\footnotetext{
${ }^{6}$ Artisanal fishing requires knowledge based on experience in the geographical location. Generally, it involves knowing the fishing zones, the direction of the winds and the currents, and knowing how to use the appropriate fishing gear for each species. For example, fathers teach their children that rocky areas, which are exposed to strong currents, are great fishing areas; lures preferred by different species; and the best time to capture the different species (e.g. "the sunset blinds the fish and hence it does not see the net").
} 
information about the marine environment, and this in turn is more selective than the acquaintanceship network. So, from the relation of acquaintances to the social support network (through the exchange of ecological information), the indicators of centrality and cohesion show that the networks are less dense, with less average degree, less closure and with a lower indicator of reciprocity. In the same line, they are more centralized, with greater average distance and greater diameter.

\section{TABLE 3}

Through the application of the QAP procedure, it was verified that there is a significant association between the ecological knowledge network and the social support exchange network ( $r=0.515, p<.0001)$. On the other hand, the network of acquaintances has a moderate-low association with the ecological knowledge network $(r=0.412, p<.0001)$ and with the support network $(r=0.306, p<.0001)$. This association was confirmed with a regression analysis using the Double Dekker Semi-Partialling MRQAP Method to predict the ecological knowledge exchange network as a function of acquaintance relationships and supportive relationships. The other two networks account for 33 percent of the variance of ecological information exchange $(p<.0005)$. There is, therefore, some mutual dependence between the three types of relationships.

The following analyses focus on the multiple networks of relationships, which combines the three above. It is the most selective relationship matrix, in which it is considered that there is a link between boat skippers when they are known, they share information about the ecological environment and they exchange social support. That is, are analyzed those strong ties in which the three types of exchanges occur in the same interpersonal relationship.

\subsection{Social networks of vessel skippers according to fishing zones}

Figure 4 presents the structure of the strong relationships between the skippers of artisanal boats anchored in Lobitos. In general it is a dense and cohesive network, in which all fishermen are highly integrated. They form an organic unit, as is the case with traditional rural communities. In fact, the core-periphery structure has a relatively large core, consisting of 20 boats (i.e., 46.5 percent of the total number of players). On the periphery, there are fishermen who go to sea with less regularity because they do some other work ashore, such as public safety (known in Peru as "serenazgo") or public cleaning. The vessels that make up the nucleus fish 232 days a year on average, while boats on the periphery of the network fish 213 days on average.

A small group of 6 skippers stand out because they are especially well connected locally and / or maintain frequent relations with vessels of other coves outside Lobitos (nodes 1, 12, 19, 26, 28, 38 in Figure 4). Among the most prominent actors in the community are some who have held institutional posts. For example: 38 was Deputy Mayor in the Municipality District of Lobitos; 12 was President of the fishing Guild of Lobitos; and 1 was President of the Catholic Community "Weddings at Cana". 
Actors who are better connected to other coves are more likely to fish in the areas of Cabo Blanco and Los Órganos, close to these other fishing enclaves (e.g. 26, 28 and 1). Also in some cases they have relatives or have lived temporarily in other fishing enclaves (this is the case of 26 and 12). When Lobitos was still a military base, there were cases where the army appropriated fishing to feed the troops, among other abuses to the local population. This caused some families to emigrate to other fishing enclaves of the coast and, after returning, have maintained ties with them over time.

In order to assess the incidence of preferred fishing zones in the relationship patterns between vessels, the network was divided into three groups (corresponding to the three clusters described in Table 2). Then the index between the external and internal relations was calculated (i.e., with boats from the same area or from another area). Vessels fishing predominantly in the intermediate zone is the only subgroup with a negative index $(E-I=-0.004)$. Boats fishing in the areas closest to the coast are significantly connected to the other two groups ( $\mathrm{E}-\mathrm{I}=0.622)$. The group of distant fishing has an index which also tend to be related to external relations $(E-I=0.470)$.

The group that fish predominantly in the intermediate zone is the most numerous (representing more than half of the group of artisanal fishermen) and has a central role in the articulation of relations. The density matrix reveals the hinge role of the second conglomerate in the network of boats. Those that fish in the intermediate zones (Cluster 2 ) are the group with a higher density of intra-group relations (0.583). It is also the group that stands out for its greater density of intergroup relations, both with those who fish in the vicinity of the coast and with those who move farther to make their catches. In addition, it has a greater proportion of local leaders (the most popular or sociable skipper boats), compared to the other two zones.

The vessels of this second cluster stand out among the actors with more connectivity outside the Lobitos enclave. For example, 5 of the 7 most central actors in the 2-mode network fall into this category. It is also interesting to note that the two groups who fish close to the coast (clusters 1 and 2) have contact with more vessels from other enclaves than those fishing in more remote areas (cluster 3 ). Specifically, vessels that fish up to six miles from the shore are related on average to 2.45 vessels of other fishing enclaves, while those fishing between six and ten miles are connected on average to 1 vessel from other fishing enclaves $(t=2.074, p<.044)$.

Fishing areas seem to be largely determined by the small storage capacity and the few steamboats on the vessel. The area called "center" by the fishermen has some of the most required fish species on the market, and allows the exchange of information on currents and other factors that affect daily fishing productivity. The data show a slight general trend toward heterofilia, that is, a tendency to relate to boats from other fishing areas.

FIGURE 4

4.6. New tourist and heritage uses in the fishing sector 
In recent years Lobitos has experienced an increase in tourism. The strong winds generate a long, tubular wave highly appreciated by the surfers. The increase in the number of tourists is reflected in the expansion of hotels and restaurants in the locality. As mentioned already, artisanal fishermen generally maintain an open attitude towards the tourism sector. While the oil industry and industrial fishing are perceived as threats to artisanal fishing, Lobitos fishers see tourists as potential consumers, as well as an opportunity to improve commerce, through local restaurants.

Accordingly, they express a positive opinion on the possible realization of tourism activities linked to fishing. The fishermen surveyed think that it is necessary to promote artisanal fishing in Lobitos and consider that the cultural heritage of fishing needs to be recognized (Table 4). They believe that the views of fishermen are not taken into account in the fisheries sector and that there are insufficient opportunities for participation, either in the port or in public administration. Moreover, in general they are quite favorable towards the new tourist and environmental and heritage uses of fishing. ${ }^{7}$ In fact, promotion of tourist activities stands out above the other factors. An example of this is the case of a fisherman who has adapted his boat to take tours with tourists and introduce them to the fishing activity.

\section{TABLE 4}

Through the systematic comparison between clusters, with the application of the nonparametric Mann-Whitney test, some significant differences in the attitudes of the respondents according to the preferred fishing zones were observed. Fishermen from intermediate zones affirm more strongly the importance of fishing $(U=160, p<.029)$ and the cultural value of fishing $(U=161.5, p<.039)$, compared with fishermen in the "outside" area. They also have on average more years dedicated to the fishing activity $(U=150.5, p<.032)$, compared to the fishers of the "outside" area. When compared to those who prefer to fish on the shore, those in intermediate zones are more aware of the need to take into account the opinion of the fishing sector $(U=49, p<.023)$. Finally, fishermen in intermediate areas are more likely to explain child labor in the sector as a need to learn a job, compared to fishermen in areas near the shore $(U=78, p<.041)$.

Again it is the group of the intermediate zone that presents a clear difference with respect to the other two groups. Fishermen in the "center" seem to show a greater involvement in the fishing sector and are more aware of the need to defend artisanal fishing.

\section{Discussion}

The fishermen of Lobitos have always lived with the threat of losing their catch because of sea lions. This archetype of relationship seems to have been reproduced in its

\footnotetext{
${ }^{7}$ Consistent with this, the institution that receives a more positive evaluation is an international NGO of surfers who implement cooperation for development initiatives $(M=1.72$, $S D=1.95$ ); while the organizations receiving a lower score are the oil companies, both the company of Korean/Colombian capital $(M=-1.25, S D=2.84)$ and the company of Chinese capital $(M=-1.25, S D=2.70)$. On a scale ranging from -4 ("Very Negative") to 4 ("Very Positive"), 0 being the midpoint or "Neutral" of the gradation.
} 
interactions with the army, the oil companies, and the industrial fleet. Artisanal fishermen are a group with little power. Both the place in which they reside and their catch potential is at the expense of third parties. The army moved the neighborhood in which they lived, the oil platforms have occupied their traditional fishing grounds, and the industrial fleet makes incursions below 5 nautical miles, a space reserved for artisanal fishing. In all these cases the artisanal fishermen have reacted with the same fatalism with which they assume the presence of the sea lions, trying to adapt to the circumstances (Querevalú Miñán, 2016).

However, with the tourism sector, which has begun to develop due to favorable conditions for surfing, a different type of relationship is observed: more receptive attitudes on the part of the fishing community. While oil companies and fish processing firms have generated an attitude of self-defense from such a cohesive community, artisanal fishermen see commercial opportunities in the increase of tourists, and they are even in favor of diversification of the sector with tourism and heritage activities. This does not necessarily mean that tourism does not have a negative impact, but rather that there is a greater willingness of the local community to adopt new roles and initiate change processes related to the tourism sector. For example, women, traditionally attached to the role of housewives, are beginning to be incorporated in alternative labor niches, as a way of facing the reduction of income in the fishing sector (Godden, 2013).

Artisanal fishing activities on the coast of Peru operate in a poorly regulated environment, with low intervention by the public administration. Following the installation of oil platforms, the Ministry of Energy and Mines introduced environmental impact studies as a requirement. Since 2011, the Environmental Assessment and Oversight Agency (OEFA) has audited the social and environmental measures that are required for hydrocarbon projects. However, in the case of Lobitos, the influence of the local community is generally limited. The fishing community supports the implementation of co-management strategies and participatory governance to contribute to the empowerment of the fishing sector. In those cases in which forms of productive coexistence between sectors are observed, compensatory actions tend to occur that seek to balance the power of the different actors involved. In the case of the Norwegian oil industry, the government has introduced regulations to prevent its environmental impact and mitigate its influence on the fishing sector.

The fishermen have been relegated to a secondary role, while significant changes took place around them. The platforms were located in a common property space, and the area around them has been primarily owned by the Peruvian state and then by foreign private companies (Querevalú Miñán, 2016). The industrial fishing of the anchovy was centralized by the Peruvian state, coinciding with the nationalization of the sector (Aguilar-Ibarra, Reid \& Thorpe, 2000; Thorpe et al., 2000; Weidner \& Hall, 1993), even though it exceeded the maximum sustainable catch (Boerema \& Gulland, 1973). In fact, the volume of the fishing fleet in general has grown above the fishing potential of the area (Estrella et al., 2000; Alfaro-Shigueto, 2010). In this context, artisanal fishermen 
have developed a kind of learned defenselessness and are skeptical about the proposals to establish the first Marine Landscape Reserve of the Coast of Peru in the north coast.

This case study allowed us to observe that the networks of relationships between vessels are organized according to the preferred fishing distance. Artisanal fishers are divided into three groups, depending on whether their fishing effort is concentrated in the areas near the shore, in an intermediate area (between three and six miles), or directly outside the restricted area for artisanal fisheries. The group that concentrates in the intermediate zone has the most important role in the network: specifically, they have a greater number of local leaders, are better connected with other coves and play an intermediary role among the three subgroups of fishermen. This group is strongly connected to the traditions and values of artisanal fishing, and has a broader vision of the functioning of the ecosystem in Lobitos. This observation coincides with other findings in different contexts, whereby the fishing distance influences the formation of clusters of relationships, and is related to heterofilia dynamics depending on the fishing zones (Maya-Jariego, Florido \& Sáez, 2017). The segmentation of the network by usual fishing zones can be used as an indicator of the readiness of the community for the incorporation of new economic and cultural heritage uses in the fishing sector, and it is also an indirect indicator of the relative power in the fishing community.

On the northern coast of Peru, other small-scale fishing communities are scattered along the coast. Usually these are very cohesive clusters, with a high local density. However, in Lobitos it was observed that a few individuals are connected with members of other coves and tend to have a leadership role in their own community. These individuals, who have experienced internal migrations or have their families distributed along the coast, are aware of variations in ocean currents and are an important source of ecological information for the local community. This coincides with other studies that highlight the importance of support exchanges in cohesive groups, along with the role of mediators in the integration of local ecological knowledge (Crona \& Bodin, 2011; Maya-Jariego, Holgado \& Florido, 2016; Sandström, 2011).

\section{Conclusions}

This paper has reviewed the role of economic actors that endanger the survival economy of artisanal fishermen communities on the northern coast of Peru. This occurs in a context in which there is a decline in the productivity of this area of the Pacific Ocean (Godden, 2013). Among other observations, it was found that:

- The communities of artisanal fishermen are a group with little power, highly pressured by the activities of oil platforms companies and the industrial fishing fleet. In this scenario, participatory governance instruments that balance the power of actors and establish regulations that protect the traditional fishing sector are lacking. In fact, the "socio-institutional mechanisms governing people's access to fisheries resources -rather than the resources themselvesplay such a critical role in vulnerability to poverty" (Béné, 2003, p.949). 
- The fishermen of Lobitos have, instead, an open attitude towards the new tourist and heritage uses of the fishing, coinciding with the recent tourist development linked to the practice of surfing. These types of activities, which are not perceived as detrimental to the community, probably have a greater potential to generate transformations in small-scale fisheries in the medium term. Some segments of the fishing communities are willing to share the fishing activity with the tourist activity, or even incorporate tourist and heritage uses in boats, clearly perceiving such changes as positive development through which they also can take advantage.

- Social networks between skippers of artisanal boats are based on fishing distance and preferred catch areas. The vessels fishing in the intermediate zone are more prominent socially at the local level, and also have key information on marine currents through their connection with vessels from other coves on the northern coast of Peru. In fact, heterofilia by fishing zones may indirectly have a positive effect on the conservation of marine resources (Maya-Jariego, Florido \& Sáez, 2017).

\section{References}

Acheson, J. M. (1988). The Lobster Gangs of Maine. Hanover: The New England University Press.

Agüero, M. (1992). La pesca artesanal en América Latina: una visión panorámica. En M. Agüero (Ed.), Contribuciones para el estudio de la pesca artesanal en América Latina. ICLARM Conference Proceedings Contribution No. 835, Manila, Philippines (1992), pp. 1-27.

Aguilar-Ibarra, A. Reid, C., \& Thorpe, A. (2000). The political economy of marine fisheries development in Peru, Chile and Mexico. Journal of Latin American Studies, 32(02), 503-527.

Alfaro-Shigueto, J., Mangel, J.C., Pajuelo, M., Dutton, P., Seminoff, J. A. \& Godley, B. J. (2010). Where small scale can have a large impact: Structure and characterization of small-scale fisheries in Peru. Fisheries Research, 106, 8-17.

Allison, E. \& Ellis, F. (2001). The livelihood approach and management of small-scale fisheries. Marine Policy, 25, 377-388.

Béné, C. (2003). When fishery rhymes with poverty: a first step beyond the old paradigm on poverty in small-scale fisheries. World development, 31(6), 949-975.

Begossi, A. (2006). Temporal stability in fishing spots: conservation and co-management in Brazilian artisanal coastal fisheries. Ecology and Society, 11(1): 5.

Boerema, L. K. \& Gulland, J. A. (1973). Stock assessment of the peruvian anchovy (Engraulis ringens) and management of the fishery. Journal of the Fisheries Research Board of Canada, 30, 2226-2235.

Borgatti, Steven P.; Everett, Martin G. and Freeman, Linton C. (2002). Ucinet 6 for Windows: Software for Social Network Analysis. Harvard, Massachusetts: Analytic.

Brandes, Ulrich and Wagner, Dorothea (2004). Visone - Analysis and Visualization of Social Neworks. In: Jünger, M. and Mutzel, P. (eds). Graph Drawing Software. Verlag: Springer. 
Borch, T. (2004). Sustainable management of marine fishing tourism. Some lessons from Norway. Tourism in Marine Environments, 1(1), 49-57.

Castilla, J. C. \& Fernández, M. (1998). Small-scale benthic fisheries in Chile: on co-management and sustainable use of benthic invertebrates. Ecological Applications, 8 (1), 124-132.

Chen, C. L. (2010). Diversifying fisheries into tourism in Taiwan: Experiences and prospects. Ocean \& Coastal Management, 53(8), 487-492.

Cormick, G. W. \& Knaster, A. (1986). Oil and fishing industries negotiate: mediation and scientific issues. Environment, 28 (10), 6-30.

Crona, B., \& Ö. Bodin. (2011). Friends or neighbors? Subgroup heterogeneity and the importance of bonding and bridging ties in natural resource governance, p. 206-234 in Ö. Bodin, and C. Prell, ed. Social Networks and Natural Resource Management: Uncovering the Fabric of Environmental Governance. Cambridge University Press, New York.

Csirke, J. (1980). Recruitment in the Peruvian anchovy and its dependence on the adult population. ICES Rapports et Procès-Verbaux des Réunions, 177, 307-313.

Estrella, C., Guevara-Carrasco, R., Palacios, J. Avila, W. \& Medina, A. (2000). Informe estadístico de los recursos hidrobiológicos de la pesca artesanal por especies, artes, meses y caletas durante el segundo semestre de 1999. Instituto del Mar del Perú. Informe no 151. La Punta, Callao.

Estrella, C. \& G. Swartzman. (2010). The Peruvian artisanal fishery: changes in patterns and distribution over time. Fisheries Research, 101, 133-145.

FAO, 2000. Informe del taller sobre manejo y asignación de recursos pesqueros a pescadores artesanales en América Latina. Valparaíso, Chile, 25-28 de abril del 2000.

Fabinyi, M. (2008). Dive tourism, fishing and marine protected areas in the Calamianes Islands, Philippines. Marine Policy, 32(6), 898-904.

Fabinyi, M. (2010). The intensification of fishing and the rise of tourism: competing coastal livelihoods in the Calamianes Islands, Philippines. Human Ecology, 38(3), 415-427.

Flache, A., \& Macy, M. W. (1996). The weakness of strong ties: Collective action failure in a highly cohesive group. Journal of Mathematical Sociology, 21(1-2), 3-28.

Godden, N. J. (2013). Gender and Declining Fisheries in Lobitos, Perú: Beyond Pescador and Ama De Casa. In Alston, M. \& Whittenbury, K. (Eds.), Research, action and policy: Addressing the gendered impacts of climate change (pp. 251-263). Springer Netherlands.

Hall, C. M. (2001). Trends in ocean and coastal tourism: the end of the last frontier?. Ocean \& Coastal Management, 44(9), 601-618.

Jentoff, S. (2000). The community: a missing link of fisheries management. Marine Policy, 24, 53-59.

Lloret, J., Cowx, I. G., Cabral, H., Castro, M., Font, T., Gonçalves, J. M., Gordoa, A., Hoefnage, E., Matic-Skoko, S., Mikkelsen, E. \& Morales-Nin, B. (2016). Small-scale coastal fisheries in European Seas are not what they were: Ecological, social and economic changes. Marine Policy. http://dx.doi.org/10.1016/i.marpol.2016.11.007 
Maya-Jariego, I., Florido, D. \& Sáez, J. (2017). Redes de consejo y apoyo social de las embarcaciones autorizadas a pescar en la reserva de la desembocadura del Guadalquivir: tres estrategias de pesca desde el puerto de Chipiona. REDES. Revista Hispana para el Análisis de Redes Sociales, 28 (1) 32-46.

Maya-Jariego, I., Holgado, D. \& Florido, D. (2016). Relations between professional groups in the Atlantic and Mediterranean fishing enclaves of Andalusia (Spain): a personal networks approach with clustered graphs. Marine Policy, 72, 48-58.

Miller, R. (1982). Small Business in the Peruvian Oil Industry: Lobitos Oilfields Limited before 1934. The Business History Review, 56(3), 400-423.

Oracion, E. G., Miller, M. L., \& Christie, P. (2005). Marine protected areas for whom? Fisheries, tourism, and solidarity in a Philippine community. Ocean \& Coastal Management, 48(3), 393410.

Palmer, C. (1990). Telling the truth (up to a point): radio communication among Maine lobstermen. Human Organization, 49(2), 157-163.

Querevalú Miñán, J. F. (2016). Producción pesquera artesanal. Estudio de caso pescadores artesanales lobiteños, barrio primavera, distrito de Lobitos, provincia de Talara, Piura. 20122015. Tesis de Licenciatura en Antropología. Universidad Nacional Federico Villarreal. Lima, Perú.

Roemer, M. (1970). Fishing for Growth, Export Led Development in Peru, 1950-1967. Harvard University Press: Cambridge, MA, USA.

Salas, S., Chuenpagdee, R., Seijo, J. C., \& Charles, A. (2007). Challenges in the assessment and management of small-scale fisheries in Latin America and the Caribbean. Fisheries Research, 87(1), 5-16.

Sandström, A. (2011). Social networks, joint image building, and adaptability: the case of local fishery management. In Bodin, Ö \& Prell, C. (Eds). Social Networks and Natural Resource Management: Uncovering the Fabric of Environmental Governance. New York: Cambridge University Press.

Solstrand, M. V. (2013). Marine angling tourism in Norway and Iceland: Finding balance in management policy for sustainability. Natural Resources Forum, 37(2), 113-126.

Stepanova, O. (2015). Conflict resolution in coastal resource management: Comparative analysis of case studies from four European countries. Ocean \& Coastal Management, 103, 109-122.

Thorpe, A., Aguilar-lbarra, A. \& Reid, C. (2000). The new economic model and marine fisheries development in Latin America. World Development, 28 (9), 1689-1702.

Uhre, A. N. \& Leknes, E. (2017). When the oil and fishing industries live side by side. Marine Policy, 75, 108-115. http://dx.doi.org/10.1016/i.marpol.2016.11.001.

Vølstad, J. H., Korsbrekke, K., Nedreaas, K. H., Nilsen, M., Nilsson, G. N., Pennington, M., Subbey, S. \& Wienerroither, R. (2011). Probability-based surveying using self-sampling to estimate catch and effort in Norway's coastal tourist fishery. ICES Journal of Marine Science: Journal du Conseil, fsr077. 
Voyer, M., Barclay, K., Mcllgorm, A., \& Mazur, N. (2017). Connections or conflict? A social and economic analysis of the interconnections between the professional fishing industry, recreational fishing and marine tourism in coastal communities in NSW, Australia. Marine Policy, 76, 114-121.

Weidner, D., \& Hall, D. (1993). World fishing fleet: an analysis of distant-water operations, pastpresent-future: vol. 4, Latin America. Office of International Fisheries, National Marine Fisheries Service, U.S. Department of Commerce, Silver Spring, Maryland.

Young, E. H. (1999). Balancing conservation with development in small-scale fisheries: is ecotourism an empty promise? Human Ecology, 27(4), 581-620. 
Table 1. Distribution of platforms, fishing points and catch time by fishing zone

\begin{tabular}{lccccc}
\hline Fishing zones & $\begin{array}{c}\text { Number of } \\
\text { fishing } \\
\text { spots }\end{array}$ & $\begin{array}{c}\text { Number of } \\
\text { oil } \\
\text { platforms }\end{array}$ & \% average fishing time & SD \\
\hline Shore $\quad<3$ miles & 23 & 15 & 31.81 & 26.44 \\
Center $\quad$ From 3 to 6 miles & 13 & 12 & 41.23 & 25.14 \\
Outside & $>$ 6 miles & 22 & 8 & 26.93 & 27.65 \\
\hline
\end{tabular}


Table 2. Centroids of the final clusters in the distribution of time by fishing zones

\begin{tabular}{lccc}
\hline & Cluster 1 & Cluster 2 & Cluster 3 \\
Near & Intermediate & Distant \\
& $(\mathrm{n}=9,20.9 \%)$ & $(\mathrm{n}=22,51.16 \%)$ & $(\mathrm{n}=12,27.9 \%)$ \\
\hline Shore & 75.56 & 24.92 & 11.67 \\
Center & 18.89 & 60.15 & 23.33 \\
Outside & 5.56 & 14.92 & 65 \\
\hline
\end{tabular}


Table 3. Measures of centrality and cohesion of the networks

\begin{tabular}{lllll}
\hline & Acquaintances & $\begin{array}{l}\text { Ecological } \\
\text { knowledge }\end{array}$ & $\begin{array}{l}\text { Social } \\
\text { support }\end{array}$ & $\begin{array}{l}\text { Multiple } \\
\text { relationship }\end{array}$ \\
\hline Density & 0,793 & 0,559 & 0,436 & 0,363 \\
Average degree & 33,326 & 23,488 & 18,326 & 15,256 \\
Degree centralization & 0,217 & 0,462 & 0,591 & 0,568 \\
Closure & 0,861 & 0,708 & 0,609 & 0,527 \\
Average distance & 1,207 & 1,447 & 1,557 & 1,647 \\
Diameter & 2 & 3 & 3 & 3 \\
Arc reciprocity & 0,811 & 0,659 & 0,541 & 0,488 \\
Mutuals & 0,643 & 0,369 & 0,236 & 0,177 \\
Asymmetrics & 0,300 & 0,381 & 0,401 & 0,372 \\
\hline
\end{tabular}


Table 4. Attitudes towards tourism, environmental and heritage uses of fishing

\begin{tabular}{llc}
\hline & $\mathrm{M}$ & $\mathrm{SD}$ \\
\hline Fishing has important tourism potential & 6.06 & 1.36 \\
Tourism agencies could make a positive contribution to the fisheries sector & 5.88 & 1.11 \\
Sometimes I think that our opinion in the fishing sector is not taken into account & 5.44 & 1.22 \\
I believe that artisanal fishing should be promoted in Lobitos & 6.60 & 0.79 \\
The entities that defend the cultural heritage have a good relationship with the & 3.65 & 1.88 \\
fishing sector & & \\
We would have to improve the participation forums and the cabildos in the port & 6.27 & 0.88 \\
In the port a museum is needed to explain to the visitors the traditions of fishing & 6.55 & 0.73 \\
In this port, tourist activities linked to fishing could be introduced & 6.46 & 0.85 \\
I am happy with the opportunities of participation that the port offers & 4.48 & 1.89 \\
It is very important to address environmental and ecological issues in fisheries & 6.25 & 0.87 \\
Conserving the heritage and culture of fisheries would help improve the ports & 6.53 & 0.76 \\
I miss that people know the importance of fishing in Lobitos & 6.51 & 0.73 \\
I have a negative opinion of biological stoppages in fishing & 3.95 & 1.98 \\
Fishing boats could organize activities for tourists in this port & 6.44 & 1.19 \\
There is a need to improve participation and collaboration in the fisheries sector & 6.60 & 0.65 \\
Factors of the scale & 5.70 & 0.59 \\
Opportunities for participation & 6.21 & 0.63 \\
Tourist activities & 5.81 & 0.61 \\
Heritage and cultural value & 5.10 & 1.06 \\
Ecological aspects & &
\end{tabular}




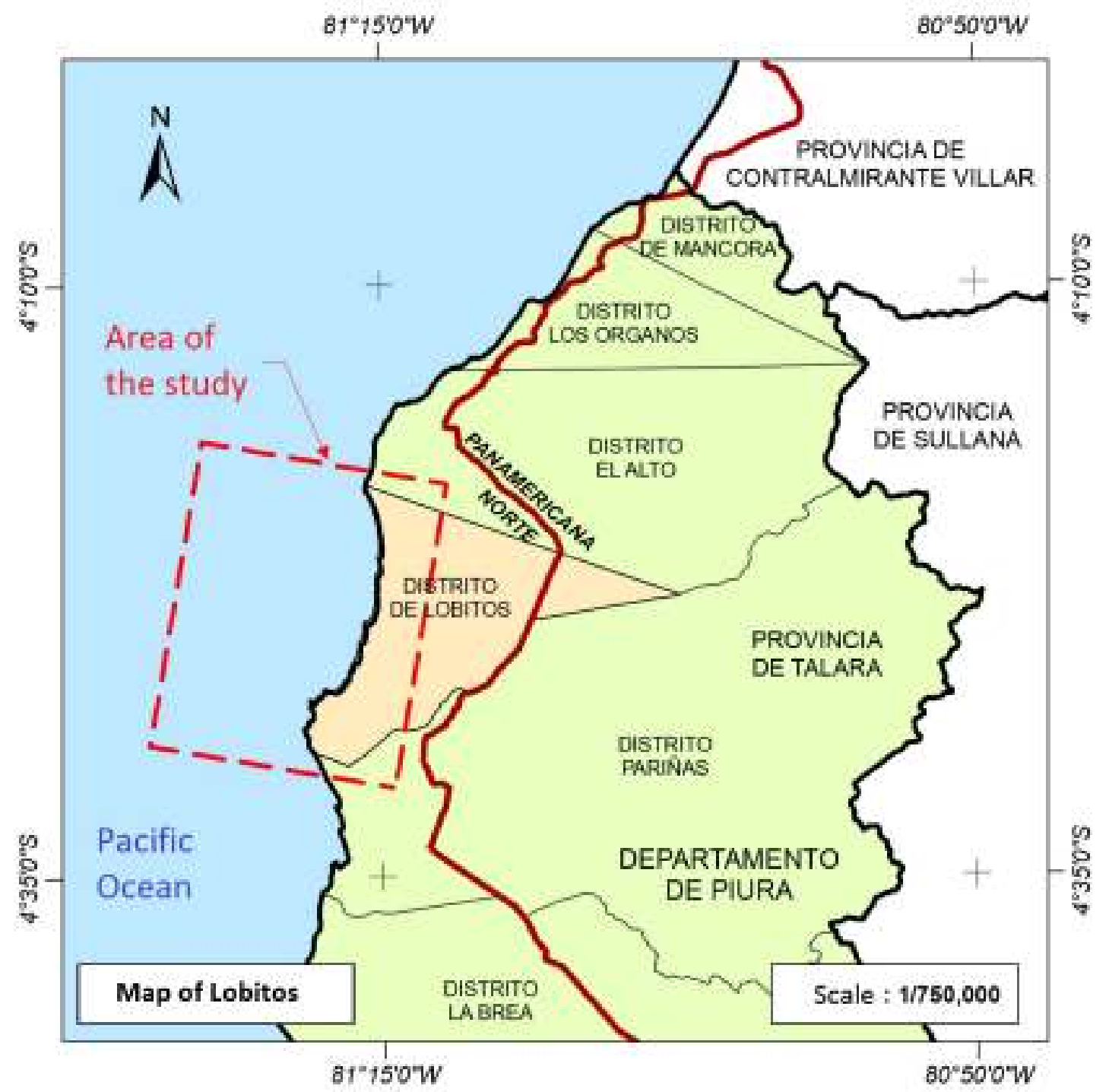

Figure 1. Study area: Coast of Lobitos in the province of Talara (Peru). 


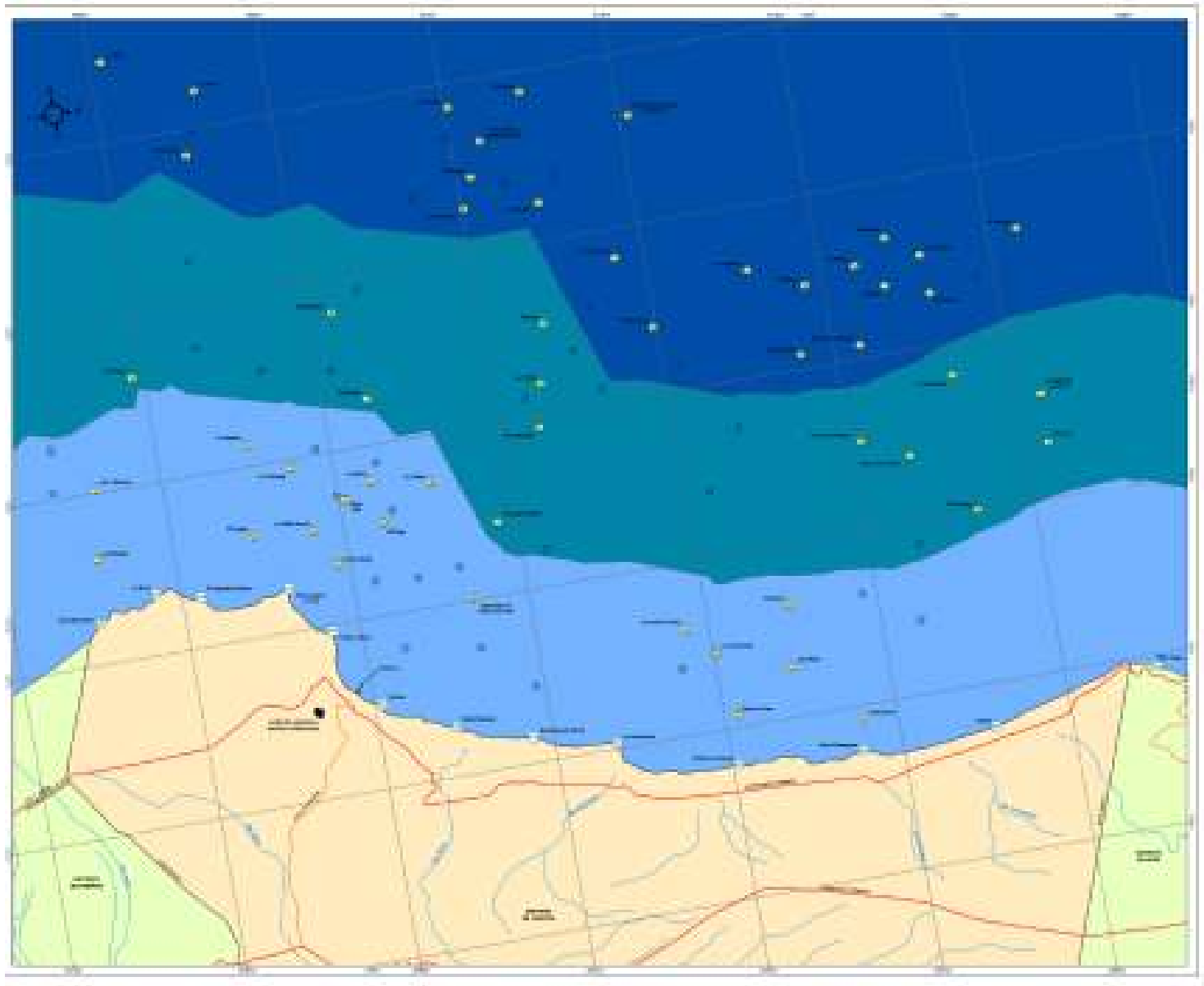

Figure 2. The three fishing areas in Lobitos. The three stripes represent the shore, the center and "outside", using the terminology of the fishermen. Yellow circles indicate fishing spots according to informants. Squares are oil platforms. Source: Querevalú Miñán, 2016. 

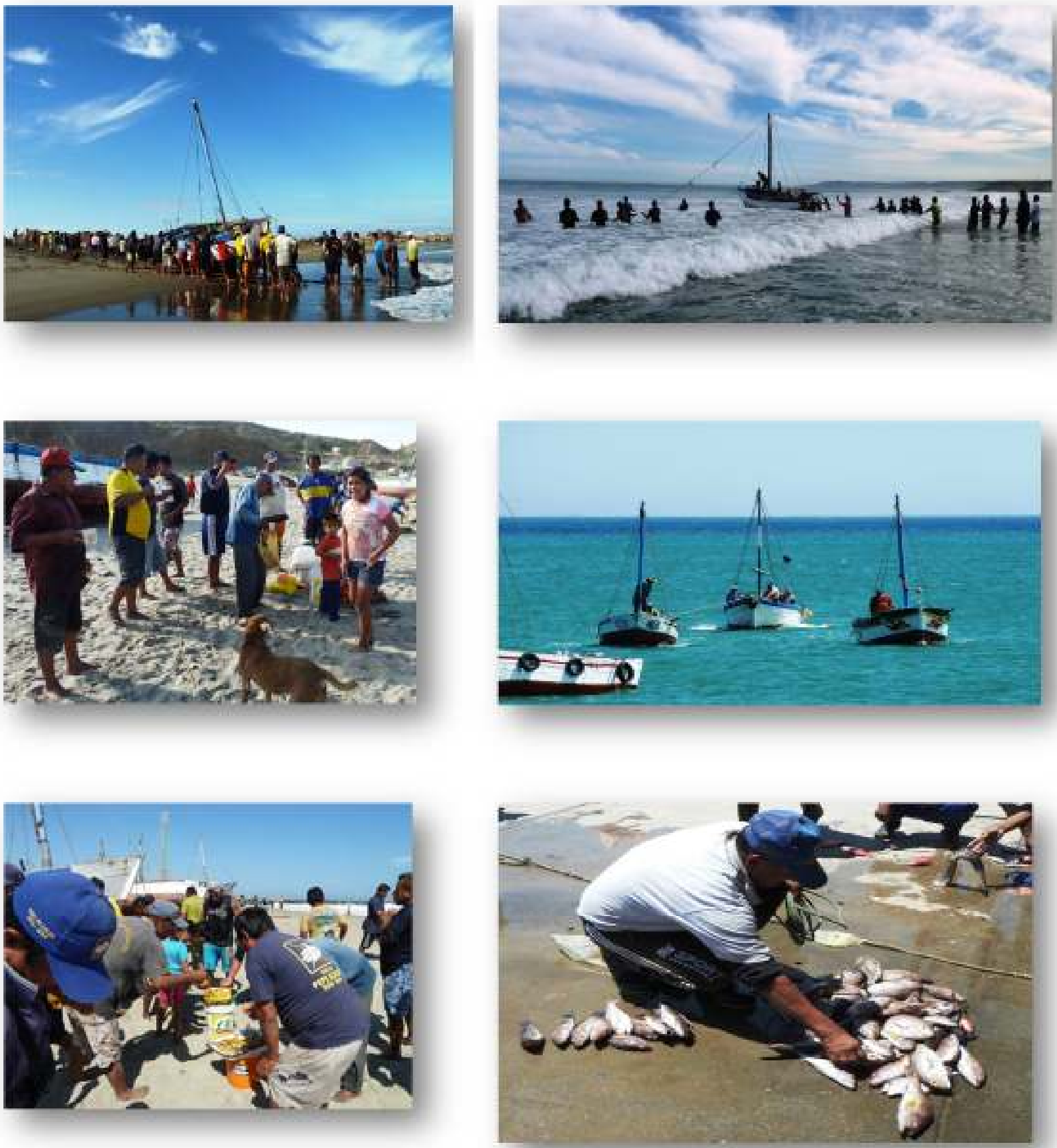

Figure 3. Collaboration between fishermen. From left to right and from top to bottom: boat stranded to land; boat launched into the sea; offering bread and coffee; damaged boat trailer; lunch provided by the aid received; distribution of the catch of the day. Photos: José $F$. Querevalú Miñán. 


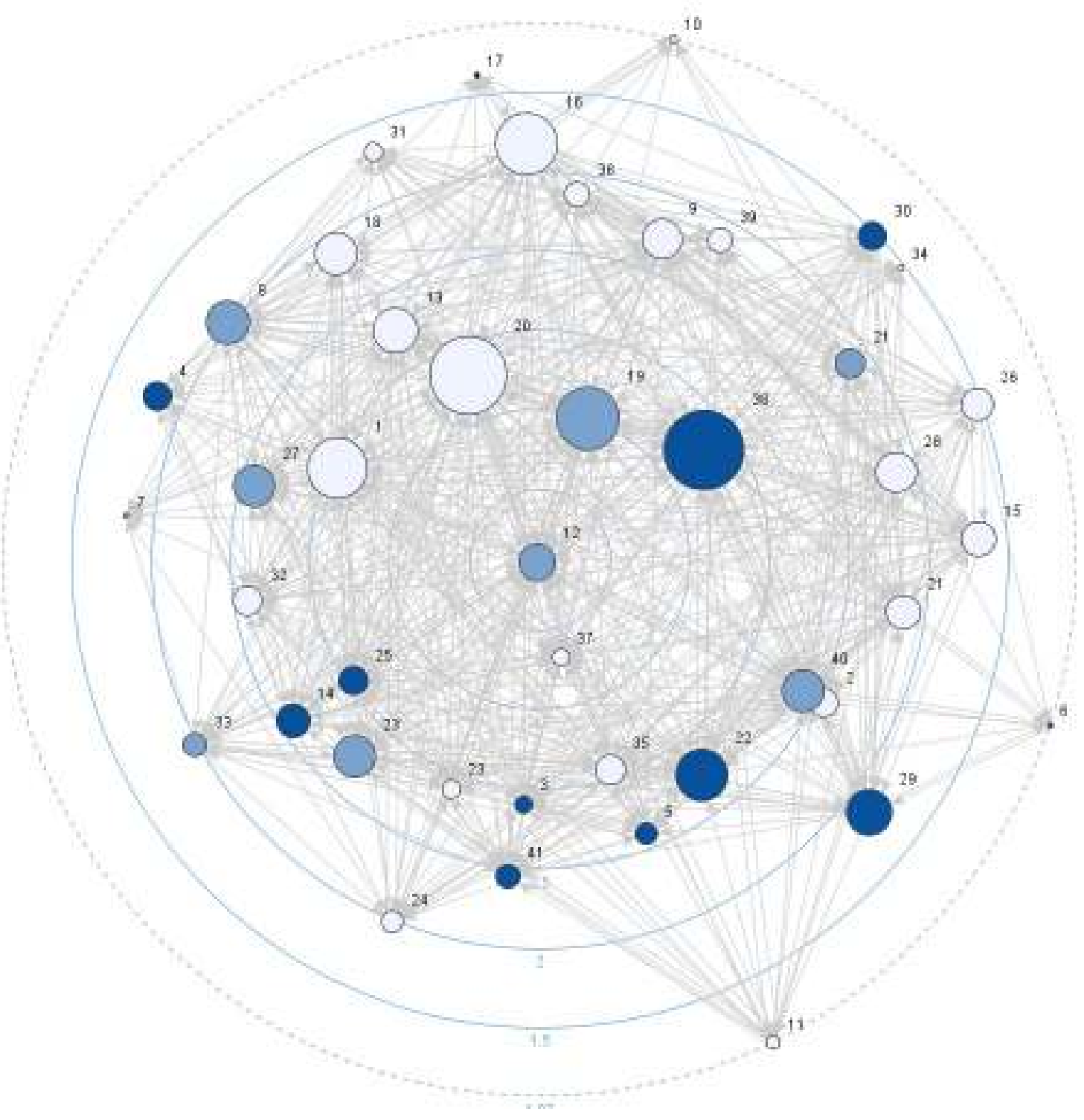

Figure 4. Network of strong ties among Lobitos boats. The nodes are arranged in concentric circles as a function of indegree. The size of the node represents the intermediation (betweenness). The color represents the preferred place of catches according to the three fishing zones. The gradation of colors represents the distance to the coast (the clearer ones fish in nearer areas and the darker ones in the more distant ones). 